\title{
Dynamics of small biotopes in Danish agricultural landscapes
}

Agger, Peder Winkel; Brandt, Jesper

\author{
Published in: \\ Landscape Ecology
}

\section{Publication date:}

1988

\section{Document Version}

Early version, also known as pre-print

Citation for published version (APA):

Agger, P. W., \& Brandt, J. (1988). Dynamics of small biotopes in Danish agricultural landscapes. Landscape Ecology, 1(4), 227-240.

\section{General rights}

Copyright and moral rights for the publications made accessible in the public portal are retained by the authors and/or other copyright owners and it is a condition of accessing publications that users recognise and abide by the legal requirements associated with these rights.

- Users may download and print one copy of any publication from the public portal for the purpose of private study or research.

- You may not further distribute the material or use it for any profit-making activity or commercial gain.

- You may freely distribute the URL identifying the publication in the public portal.

\section{Take down policy}

If you believe that this document breaches copyright please contact rucforsk@kb.dk providing details, and we will remove access to the work immediately and investigate your claim. 


\title{
Dynamics of small biotopes in Danish agricultural landscapes
}

\author{
Peder Agger ${ }^{1}$ and Jesper Brandt ${ }^{2}$ \\ ${ }^{I}$ Ministry of the Environment, The National Forest and Nature Agency, Monitoring Section, \\ Slotsmarken 13, DK-2970 Hoersholm; ${ }^{2}$ Institute of Geography, Socio-Economic Analysis \\ and Computer Science Roskilde University Centre, P.O. Box 260, DK-4000 Denmark
}

Keywords: agricultural landscape, land use, landscape pattern, landscape elements, patch, network, boundaries, connectivity, buffering zones

\begin{abstract}
The contemporary pattern of small biotopes - small uncultivated areas in the agricultural landscape, its historical development and recent trends have been studied in Eastern Denmark. The study is based on ordinance maps dating back to 1885, aerial photographs, and field studies (1981 and 1986). The development of these areas is seen in changes in agricultural production. A general decrease in the overall density, and especially in the density of the smallest, wet biotopes, is demonstrated. This change, however, is hiding a more dynamic process of removal, establishment and change within the individual biotopes. The consequences on research, monitoring and management of the agricultural landscape are discussed.
\end{abstract}

\section{Introduction}

Industrialization of agricultural production in Denmark since the second world war has changed the structure of the agricultural landscape. Agricultural land covers $65 \%$ of the national territory. Severe environmental problems and problems for recreational uses have followed. In order to understand and eventually solve some of these problems, several research programs have been started. One of these involved the study of the dynamic patterns of small uncultivated habitats (Biotopgruppen 1986), and the results of this investigation are presented here.

Hedges, roadside verges, drainage ditches, small brooks, bogs, marl pits, natural ponds, thickets, prehistoric barrows and other small uncultivated areas laying within and between the fields in the Danish terminology are named 'small biotopes'. Conceptually they correspond to the 'network' that is embedded in a 'matrix' of cultivated fields as de- fined by Forman and Godron (1986). They can also be described as 'ecotopes', the smallest unit to be studied in the landscape (Naveh 1984). Other authors use such terms as 'small scale landscape elements' (Ruthsatz and Haber 1982), 'interstitial habitats' (Moore 1977), 'remnant biotopes' (Ericsson et al. 1987) and 'biotopes in the rural landscape' (Ihse 1987).

These structures play a decisive role for all the species that are in any way dependent on fresh surface water, trees, shrubs, and perennial herbs. Further, small biotopes are important for the amenity, cultural value, and accessibility of the landscape and, hence, for its recreational potential. Finally, agriculture can be dependent on the pattern of small biotopes (Schmel and Englmaier 1982).

The general trend in agriculture has been a change from mixed farming toward more specialized and concentrated production. Formerly, average size, mixed farms of 15 ha have decreased to about one-quarter of all farms. The number of 
farms has also decreased from 203,000 in 1950 to 90,000 in 1986 . Increasingly regional concentration of production has occurred, with cattle raising mostly in western, and cereals and seeds mostly in eastern Denmark.

In contrast to the majority of other European countries, a profound reallotment of agricultural land was carried out in Denmark at the end of the 18 th century. Since this study covers a period from 1885 to the present, this means that for the whole study period all the areas attached to a single farm are clearly defined. The farmstead itself is usually situated in the middle of its holdings. This landscape is quite different from, and probably easier to study, than the former landscapes with an atomized field pattern and extended commons with indistinct boundaries. Landscape patterns, at that time, seemed to correspond more with function than territorial ownership.

Today, the appearance of the landscape is basically derived from this reallotment. In the young moraine dominated landscapes of Eastern Denmark the main events influencing the landscape pattern have been: (1) in the beginning, the construction of dikes and drainage ditches and their later removal; (2) in the second half of the 19th century marl digging which left a multitude of small marl pits in nearly every field, and (3) more continuously throughout the period, the reclamation of wetland areas through drainage, road building, and extraction of gravel. But still, the basic structures seen today were formed around the year 1800 .

The aim of this study is to understand the influences of agriculture on the landscape and on uncultivated habitats for wildlife. Therefore, we have concentrated attention on those aspects of the landscape which provide permanent or semipermanent habitat for wild species. Biotopes in non-agricultural areas and biotopes which persist for only one year were excluded from the study. The focus of the study is on what we have defined as 'small biotopes in agricultural areas' (Danish: 'smaabiotop'). A small biotope is 'an uncultivated area that is permanently covered with vegetation (or water) and situated within an agricultural area. Further, the size of the area should be more than $10 \mathrm{~m}^{2}$ and less than $20,000 \mathrm{~m}^{2}$ ( $2 \mathrm{ha}$ ) for patch-biotopes, or a length of more than $10 \mathrm{~m}$ and a width of more than $0.1 \mathrm{~m}$ for line-biotopes.

\section{Methods}

The total area of Eastern Denmark (Funen and eastward excluding the island of Bornholm) has been studied at three levels:

1. On the newest four cm maps, the signature for small biotopes have been counted and measured according to type in each of 249 evenly distributed one $\mathrm{km}^{2}$ agricultural areas (see Fig. 1).

2. In 13 two by two $\mathrm{km}$ sampling areas, all small biotopes were recorded in 1981 and 1986, and their owners interviewed about the production on the farm and the use and plans for the small biotopes.

3. In five of the 13 sampling areas, the biotopes have been followed back in time through two series of aerial photographs and four series of maps to the oldest ordinance maps from about 1885 .

The only criteria for the choice of the 249 one $\mathrm{km}^{2}$ areas was that they should be chosen immediately northeast of the point where the UTM-gridnet lines with numbers ending with 0 or 5 crossed (which covers $4 \%$ of the total area) unless more than $25 \%$ were covered with a non-agricultural area, in which case, one of the neighboring squares was chosen.

The 13 two by two km sampling areas were selected using a stratified sampling scheme related to a previous regional study (see below). The five areas chosen for historical analysis were selected so that the major landscape types were represented.

Since there is no detailed map of special landscape types in Denmark, a biotope relevant regional description was made to economize the limited resources for fieldwork. First, the development of agricultural technology and structure was seen as the main force behind the development of small biotopes in the agricultural landscape. Second, this was applied to a concrete landscape modified by physical geographic components. And third, the pattern was influenced by urbanization. Within these three groups of conditions, the following statistical data were selected to classify 115 municipalities (having an average size of $110 \mathrm{~km}^{2}$ ). 


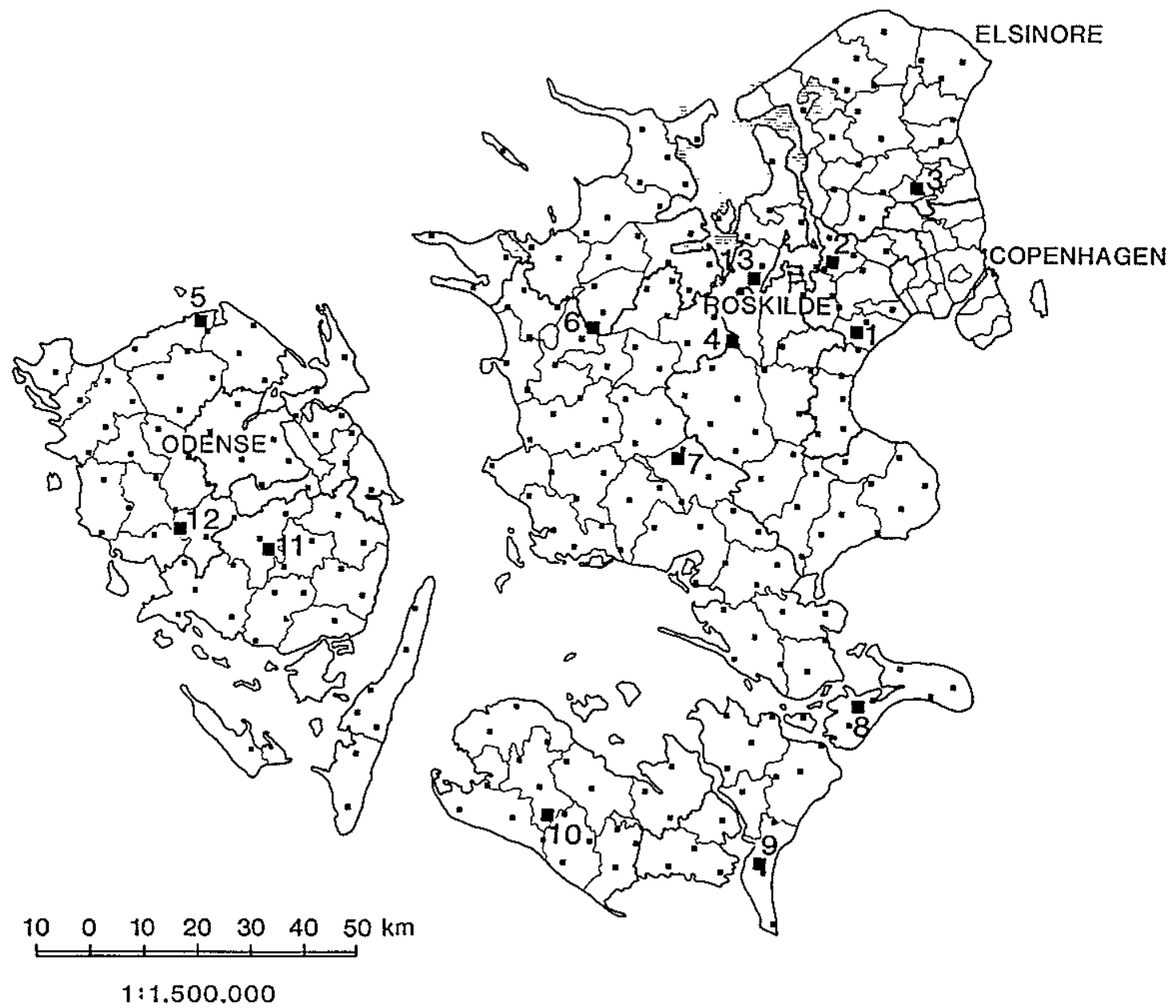

Fig. 1. The location of the 13 four $\mathrm{km}^{2}$ field survey areas (marked with black and a number), and the 249 one $\mathrm{km} \mathrm{m}^{2}$ map-based test areas in the Eastern part of Denmark.

Agricultural data:

1. Cultivated area in $\%$ of total area.

2. Area of farms $>50$ ha in $\%$ of total area cultivated.

3. Area of permanent grassland in $\%$ of total area cultivated.

4. Number of cattle per 100 ha.

Physical geographical data:

5. Area of lighter soils in $\%$ of total area.

6. Area of clay soils in $\%$ of total area.

7. Area of organic soils in $\%$ of area.

8. Density of brooks in $\mathrm{m}$ per ha.

Urban data:

9. Inhabitants per 100 ha.
10. Urban population in $\%$ of total population.

11. Town area in $\%$ of total area.

A classification of the 115 municipalities was made by principal component analysis and cluster analysis. The final classification, based on a projection of the plane given by the two first principal components, is shown on Fig. 2.

Of the eight classes recognized on Fig. 2, four classes were described as variants of the average for all of the municipalities (average classes) and the rest represented more marked deviations (diverging classes). The geographical relevance of the classifications was judged to be well-founded since a clear relation between the classification and the regionalization could be obtained, as shown in Table 1 . 


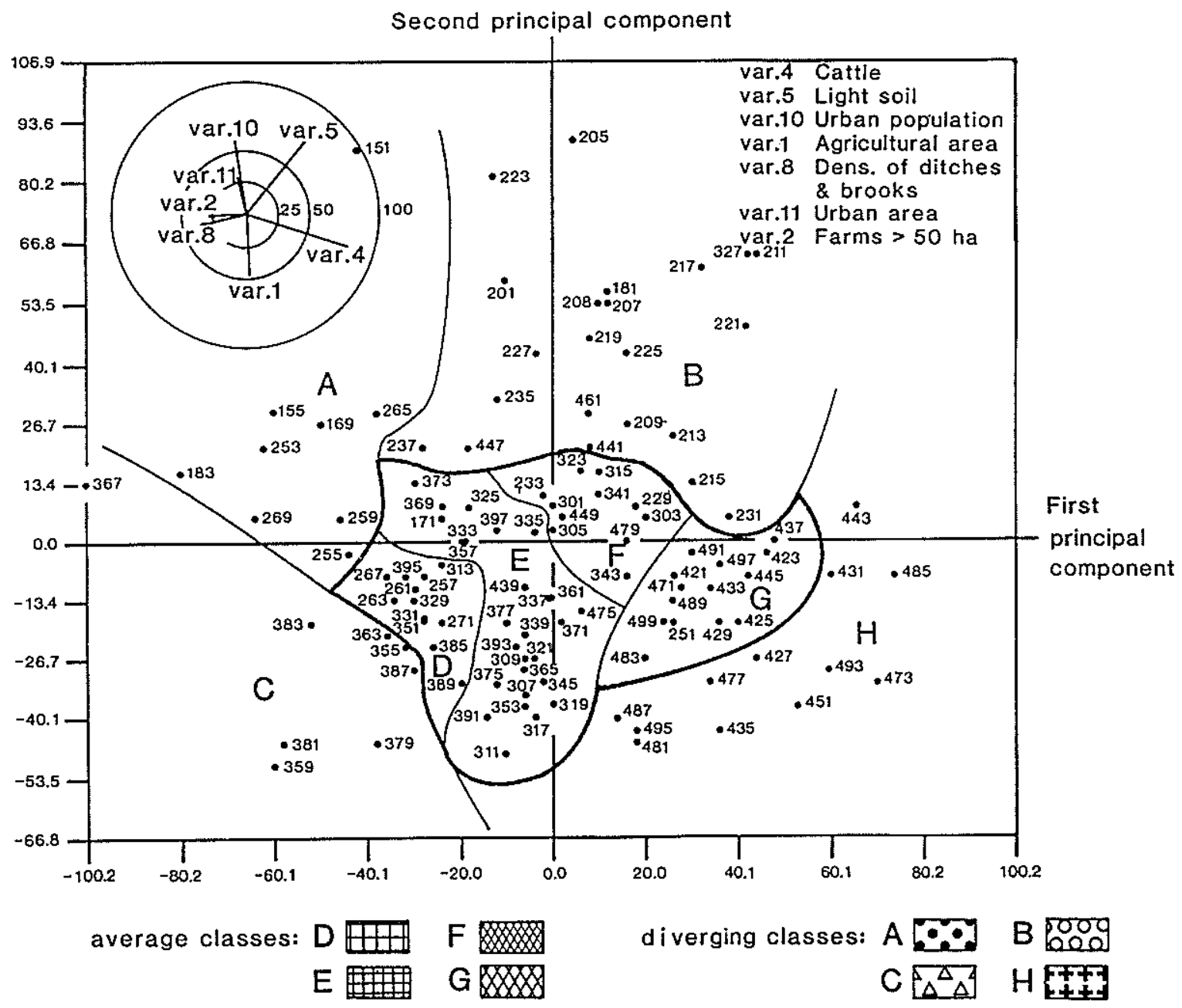

-with signatures for the corresponding regions (see fig. 3)

Fig. 2. Classification of municipalities in Eastern Denmark for small biotope related variables, based on PCA-vector 1-vector 2-plane, describing $68.6 \%$ of the total variance. The projection of the variables best correlated $(>0.25)$ with this plane are indicated on the graph.

Table 1. Relation between classes and regions of municipalities in Eastern Denmark concerning small biotope-related variables. The classes refer to Fig. 2, the regions to Fig. 3.

\begin{tabular}{lccccccccc}
\hline \multicolumn{1}{c}{ Class } & A & B & C & D & E & F & G & H & Coverage (\%) \\
\hline Region & & & & & & & & & \\
1 & 9 & & & & 1 & & & & \\
2 & & 22 & & 1 & & & & & 90 \\
3 & & & 10 & & & & & & 96 \\
4 & & & & 7 & & & & 1 & 100 \\
5 & & & 2 & 1 & 24 & & & & 86 \\
6 & & & & & & 8 & & & 100 \\
7 & & & & 1 & 1 & & 10 & & 84 \\
8 & & & & 1 & 1 & & 2 & 13 & 76 \\
\hline
\end{tabular}

The final regional description is shown in Fig. 3.

For the selection of field study areas, representative municipalities were chosen from the diverging and typical regions. Field study areas were meant to represent 'average' areas for the regions. They were supplemented with representatives of large scale landscape types (such as river-valley-bottoms, embanked areas, and dead-ice landscapes) which had not been included because the selection procedure was based on regional scale information. Thus, the field area selection procedure was made with two, probably conflicting, purposes: first, to secure a sample that was representative of small biotope in- 


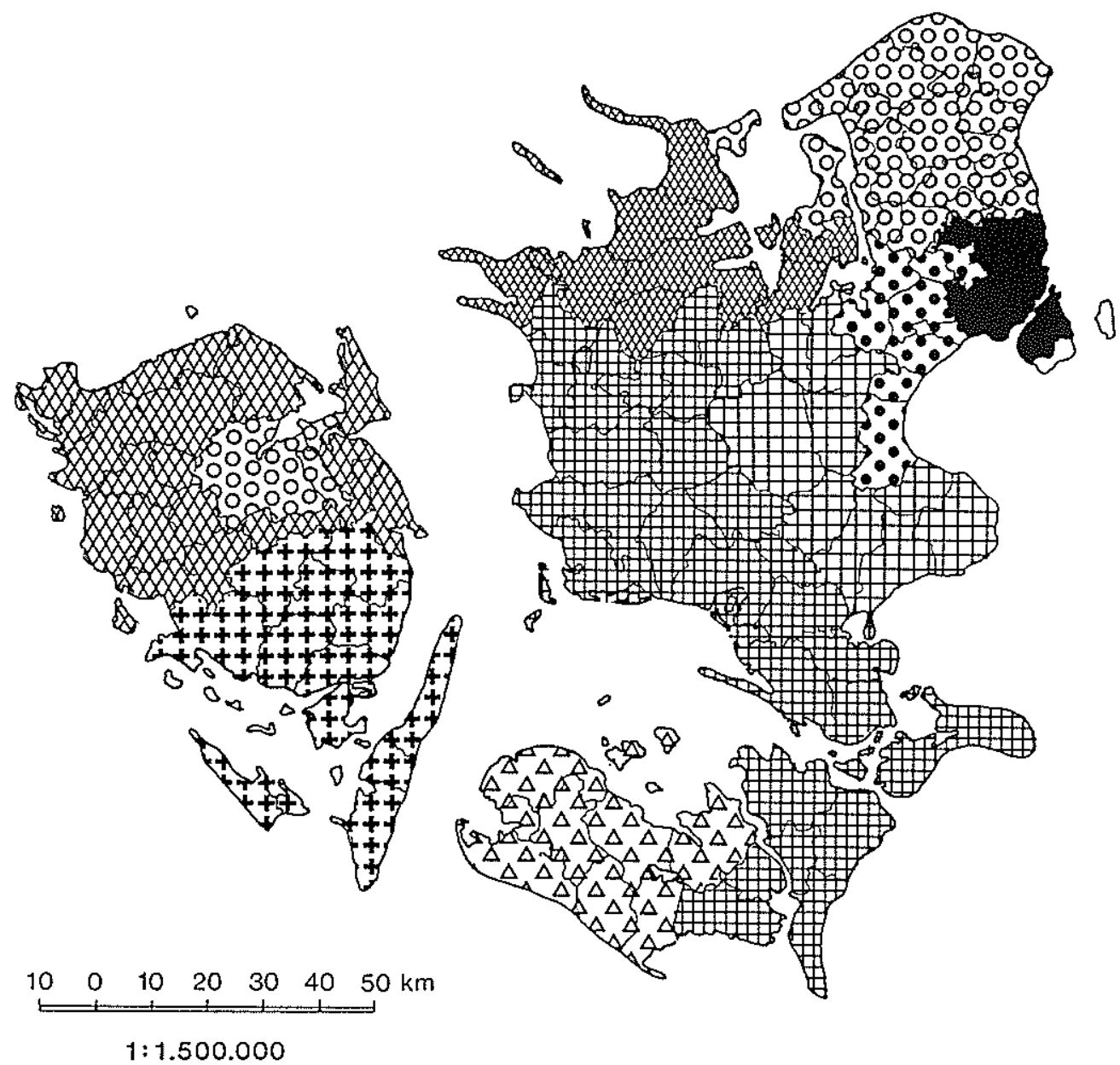

Fig. 3. Regionalization of municipalities in Eastern Denmark with small biotope related variables.

fluencing conditions in Eastern Denmark, and second, to insure that the main types of agricultural landscapes and landscape-developments were represented.

For the 249 one $\mathrm{km}^{2}$ areas, measurements of length or area were made directly from the maps using a millimeter stick and millimeter transparent paper. Readings from older maps and aerial photographs were made with a zoom-transfer-scope. With this instrument, it is possible to compare a field map with an old map, or an aerial photograph. The field location, type, size, level, coverage with trees, herbs, reeds and water and human use were recorded.

The criteria used for separating the biotopes into types is as follows:

A. The classification should correspond (include) with the definition of signatures on the maps.

B. It should, as far as possible, correspond to th common classification, expressed using the vel nacular names, for the different biotopes $i$ Denmark.

C. It should allow the fieldwork to be done with in a reasonable time.

D. It should be strictly objective and permit rept tition of the fieldwork at a later time.

The biotopes were divided into line-biotope: which are indicated on the maps with true lengt but uncertain width, and patch-biotopes. Then the were divided into wet-biotopes, with permanent $c$ semi-permanent surface water, and dry-biotope: Next, they were divided into those covered wit trees and shrubs and those without such vegetatior and finally, they were divided by function. Tr 
Table 2. Classification of small biotopes.

\begin{tabular}{|c|c|}
\hline Line-biotopes & Patch-biotopes \\
\hline 00 Field road verge & 16 Wet marl pit \\
\hline 01 Gravel road verge & 17 Other wet pit \\
\hline 02 Paved road verge & 18 Artificial pond \\
\hline 03 Avenue verge & $19 \mathrm{Bog}$ \\
\hline 04 Field divide & 20 Natural pond or lake \\
\hline 05 Hedgerow & 21 Village pond \\
\hline 06 Stone wall & 22 Alder swamp \\
\hline 07 Hedgerow on 06 & 23 Rain water basin \\
\hline 08 Dyke & 24 Dry marl pit \\
\hline 09 Hedgerow on 08 & 26 Other dry pit \\
\hline 10 Slope & 27 Barrow \\
\hline 11 Dry drainage ditch & 28 Plantation for game \\
\hline 12 Wet drainage ditch & 29 Other plantations \\
\hline 13 Canal & 30 Natural thicket \\
\hline 14 Brook & 31 Solitary tree \\
\hline 15 River & 33 Ruderal area \\
\hline 32 Railway dike & 33 Ruderal area \\
\hline 43 Treerow* & 34 Highpower el-mast \\
\hline \multicolumn{2}{|l|}{44 Treerow on 11 or 12} \\
\hline \multicolumn{2}{|l|}{45 Treerow on 08} \\
\hline \multicolumn{2}{|l|}{46 Hedgerow on 11 or 12} \\
\hline 47 Footpath & \\
\hline
\end{tabular}

*'Treerow' is a single row of equidistant planted trees.

types are given in Table 2.

There were several problems involved in making this classification (Agger and Brandt 1984; and Biotopgruppen 1986). One problem was to separate biotopes that were physically interconnected. For the line-biotopes, this problem was solved by treating the network of line-biotopes as the summed length and not as a number of , separate biotopes. Since the type may change along a line, they were divided in bits of $20 \mathrm{~m}$. In this way, for instance, a hedgerow was defined as a $20 \mathrm{~m}$ line-biotope with more than $50 \%$ coverage of trees and/or shrubs.

Whether a structure was recorded as a single biotope, i.e., a marl pit with surrounding tree covered shores, or as a conglomerate consisting of a marl pit and a thicket was judged either in the field or later when studying the old maps. The principle followed was that one biotope should be defined as the largest stretch or part of a biotope which has had $a$ unit history from the oldest map to the present.

Another problem was the validity of maps and photographs. There are three problems with using old maps. These are:
A. The choice of signatures. How have the biotopes been classified?

B. The power of dissolution of the maps: How large should a biotope be to be recorded?

C. The obsolescence of the maps: How outdated was the map at the time of issue?

The instructions for drawing the old large scale topographical maps $(1: 20000)$ have been examined and found useful, if one remembers the predominantly military purposes for the maps. For instance, behind the modern definition of dykes as more than $75 \mathrm{~cm}$ high line structures in the landscape, was a functional definition bound to what was necessary to hide a soldier with his pack. The main problem has been the character of areas indicated with signatures for bogs, leys and wet meadows and the distinction between permanent pastures and cultivated grassland. On some occasions, these signatures change back and forth over the 100 year period in a way which indicates changes in classification rather than in the landscape.

The transition from the old topographical maps (1:20000) to the modern topographical maps (1:25 000), has meant changes in the definition of types and increase of minimum size criteria for the mapping of landscape elements. Neither drainage ditches along roads, nor field borders are recorded (unless they are higher than $3 / 4 \mathrm{~m}$ above field level).

Obsolescence is always present, but is more important with the older maps where new issues often were revised only for features such as roads and buildings and not for structures of minor importance such as many of the small biotopes. With the modern photogrammatric methods of mapping, this problem can be considered of minor importance.

The overall validity of the maps was tested for the five areas that were used for historical analysis. Supposing a constant rate of change, it is possible to estimate how many different types of biotopes should have been on the maps that might have been or were issued in 1954, 1968 and 1974 by comparing with aerial photographs in these years with fieldstudies in 1981. The results are given in Table 3.

'Other roads', hedgerows and dykes nearly al- 
Table 3. The percentage of the different types of small biotopes that can be estimated to be included on maps issued in 1954 , 1968 and 1974.

\begin{tabular}{lrrr}
\hline & 1954 & 1968 & 1974 \\
\hline Field roads & 80 & 86 & 88 \\
Other roads & 104 & 97 & 99 \\
Hedgerows and dykes & 100 & 100 & 97 \\
Wet linear-biotopes & 86 & 85 & 87 \\
Wet patch-biotopes & 67 & 68 & 67 \\
Dry patch-biotopes & 66 & 75 & 91 \\
\hline
\end{tabular}

ways are indicated on the maps, but $1 / 6$ of the field roads and wet linear biotopes are missing, as are $1 / 3$ of the wet and $1 / 10$ of the dry patch-biotopes. These relations seems rather constant, with the exception of dry patch biotopes which have increased from $66 \%$ in 1954 to $91 \%$ in 1974 . Loss of the smaller part of the biotopes, along with colonization with trees and shrubs of the remaining area, which make recording more obvious, may be the explanation. To these should be added the modest field borders, the ditches along roads and the

Table 4. Distribution of line-biotopes in the 13 areas.

\begin{tabular}{|c|c|c|c|c|c|}
\hline Type & $\begin{array}{l}\text { Total length } \\
\mathrm{km}\end{array}$ & $\%$ & $\begin{array}{l}\text { Average density } \\
\mathrm{m} / \mathrm{km}^{2}\end{array}$ & $\begin{array}{l}\text { Area covered } \\
\%\end{array}$ & $\begin{array}{l}\text { Average width } \\
\text { m }\end{array}$ \\
\hline Field road verges & 31.3 & 10.8 & 645 & 9.5 & 2.7 \\
\hline Gravel road verges & 19.0 & 6.6 & 391 & 3.5 & 1.6 \\
\hline Paved road verges & 39.2 & 13.6 & 808 & 15.3 & 3.5 \\
\hline Avenue verges & 2.5 & .9 & 51 & 1.4 & 4.9 \\
\hline Field divides & 73.5 & 25.5 & 1516 & 11.5 & 1.4 \\
\hline Hedgerows & 68.6 & 23.8 & 1412 & 29.2 & 3.8 \\
\hline Dykes & 5.5 & 1.9 & 114 & 2.1 & 3.1 \\
\hline Drainage ditches & 31.2 & 10.8 & 644 & 10.2 & 2.8 \\
\hline Canals & 3.9 & 1.4 & 80 & 3.3 & 8.0 \\
\hline Brooks & 6.5 & 2.3 & 134 & 4.7 & 6.4 \\
\hline Rivers & 4.0 & 1.4 & 83 & 5.2 & 11.5 \\
\hline Slopes & 1.4 & .5 & 29 & 1.3 & 7.8 \\
\hline Railway embankments & 1.9 & .7 & 40 & 2.6 & 11.6 \\
\hline Line-biotopes & 288.5 & 100 & 5947 & 100 & 3.1 \\
\hline
\end{tabular}

Total area of line-biotopes: 88.5 ha or $1.82 \%$ of the agricultural area.

Table 5. Distribution of small patch-biotopes in the 13 areas.

\begin{tabular}{|c|c|c|c|c|c|c|}
\hline & Total number & $\%$ & Number $/ \mathrm{km}^{2}$ & $\begin{array}{l}\text { Area } / \mathrm{km}^{2} \\
\mathrm{~m}^{2}\end{array}$ & $\%$ & $\begin{array}{l}\text { Average size } \\
\mathrm{m}^{2}\end{array}$ \\
\hline Bogs & 127 & 25.2 & 2.6 & 5356 & 31.0 & 2048 \\
\hline Small lakes & 41 & 8.1 & .8 & 1977 & 11.4 & 2334 \\
\hline Marl pits & 120 & 23.8 & 2.5 & 942 & 5.4 & 387 \\
\hline Gravel pits & 11 & 2.2 & .2 & 383 & 2.2 & 1691 \\
\hline Thickets & 126 & 25.0 & 2.6 & 6970 & 40.5 & 2683 \\
\hline Barrows & 16 & 3.2 & .3 & 74 & .4 & 231 \\
\hline Solitary trees & 31 & 6.2 & .6 & 29 & .2 & 46 \\
\hline High power pylons & 7 & 1.4 & .1 & 4 & - & 29 \\
\hline Other patches & 25 & 5.0 & .5 & 1508 & 8.8 & 2944 \\
\hline All patches & 504 & 100 & 10.4 & 17243 & 100 & 1662 \\
\hline
\end{tabular}

Total area of patch biotopes: 83.6 ha or $1.72 \%$ of the agricultural area. 
Table 6. Densities of signatures for small biotopes on maps from the late 1970s expressed as the percentage of the density of the signatures on maps for the same areas in the mid 1880 s.

\begin{tabular}{|c|c|c|c|c|c|c|}
\hline Area number & 2 & 9 & 10 & 11 & 13 & $\begin{array}{l}\text { Average excluding } \\
\text { area no. } 9\end{array}$ \\
\hline Roadside verges & 96 & 177 & 55 & 76 & 63 & 72 \\
\hline $\begin{array}{l}\text { Ditches, brooks, } \\
\text { canals and rivers }\end{array}$ & 67 & 190 & 35 & 40 & 16 & 40 \\
\hline Hedgerows and dykes & 109 & 190 & 5 & 52 & 69 & 59 \\
\hline Bogs in numbers & 57 & 0 & 0 & 20 & 82 & 40 \\
\hline Bogs in area & 104 & 0 & 0 & 16 & 87 & 52 \\
\hline Ponds* in numbers & 41 & 11 & 26 & 23 & 35 & 31 \\
\hline Ponds* in area & 73 & 80 & 27 & 111 & 140 & 88 \\
\hline Thickets in number & 220 & $* *$ & $* *$ & 278 & 400 & $* *$ \\
\hline Thickets in area & 1034 & $* *$ & $* *$ & 144 & 2625 & $* *$ \\
\hline All patch-b.number & 89 & 45 & 39 & 63 & 52 & 61 \\
\hline All patch-b.area & 125 & 310 & 39 & 84 & 113 & 90 \\
\hline
\end{tabular}

* Ponds include lakes, marl pits and gravel pits.

** Percentages are not calculable as the type did not exist on the oldest maps.

Area numbers refer to the numbers in Fig. 1.

smallest biotopes, that are excluded in the mapping procedure.

Aerial photographs give a picture much closer to reality, but the interpretation may be very difficult unless maps and/or field observations are available. But having these, all biotopes can be properly localized and measured. Only a more detailed classification might give some problems, for instance, the tree and shrub coverage often will be underestimated on photographs. Agger and Jensen (1982) have estimated this bias to be about $12 \%$.

In the historical analysis, the starting point was the oldest map. On this map, each biotope was identified. From later maps, changes in type, size, or existence of biotopes were recorded for each location. These could be 'unchanged', 'changed', 'just disappeared', 'disappeared by amalgamation with a neighboring biotope', 'disappeared by being included in non-agricultural area' or 'disappeared and the area now being urbanized'. Any new biotope appearing on a map was recorded. The procedure was repeated on the maps or photographs for each period.

\section{Results}

\section{The biotope pattern contemporary densities}

The total lengths, areas and average densities of the main types of biotopes recorded in the field in 1981 are given in Tables 4 and 5. Small biotopes covered 172.1 ha or $3.5 \%$ of the agricultural areas investigated. These densities varied considerably among the 13 areas. The total density of line-biotopes varied from 3.4 to 11.3 per $\mathrm{km}^{2}$ and patch-biotopes from 4.2 to 26.9 per $\mathrm{km}^{2}$ depending on geomorphological and agricultural conditions in the area.

\section{Historical development}

The overall changes from 1884 to 1978 are given in Table 6 , where the density of signatures on the latest map is expressed as the percentage of the density in exactly the same areas as in 1884 . Four conclusions can be drawn from Table 6: (1) A tendency for the total density to decrease; (2) large differences among the different types of biotopes; (3) large differences among the different areas; (4) Patch-biotopes decreased more in number than in area. Generally, it is the smaller and the wetter biotopes that have decreased. In contrast, thickets increased considerably, but not enough to compensate for the decrease in the other types.

Area number nine deviates strongly from the others in the development of line-biotopes. This could have been forseen as it is situated in an area where a former fiord was reclaimed. The increase 
comes from building farms and roads, planting shelterbelts on the light marine soils and construction of canals and drainage ditches. Since it is atypical, this area has been excluded from the averages given in Table 6 . Still, this column should be interpreted with caution as the development of the other four areas is strikingly different. They represent four types of development rather than general trends in Eastern Denmark.

This method of calculation hides a dynamic process where former herb covered field borders may be colonized, hedgerows removed, ponds drained so they become bogs or thickets etc. The overall net changes also hide the fact that some biotopes are being removed in the same period as others of the same type are being established. In order to identify these types of changes, records have been kept for each spot that in any of the seven registrations had carried some type of biotope. Their dynamics were designated by the terms unchanged, changed type, newcomers, disappeared or intermediate, where the biotope neither appeared on the first map nor in the field registration. I.e., a 'lability-index' (LI) was computed in order to give a single expression of the relative stability of the different types of biotopes. The index is defined as the number of biotopes of a type that have been missing in the first, and/or the last registration divided by the number of all biotopes of that type. These indices will be zero where no changes have appeared, and one where everything has changed. The results of this analysis are given in Table 7 .

A comparison between Tables 6 and 7 demonstrates that net changes in the content of biotopes are hiding a far more dynamic process of biotope removal and creation. The number of patchbiotopes in the late 1970 s was $61 \%$ of what it was in the mid $1880 \mathrm{~s}$, but of these only 71 (or $16 \%$ ) have remained unchanged. The corresponding percentage for line-biotopes is $6 \%$.

Figure 4 shows, for the present stock of biotopes, the fraction that were indicated on the oldest maps. Generally, wet biotopes, together with roads and barrows, form the conservative elements in the landscape, whereas the dry patch-biotopes (plantations and gravel pits) are new.

Table 7 also unveils part of the methodological

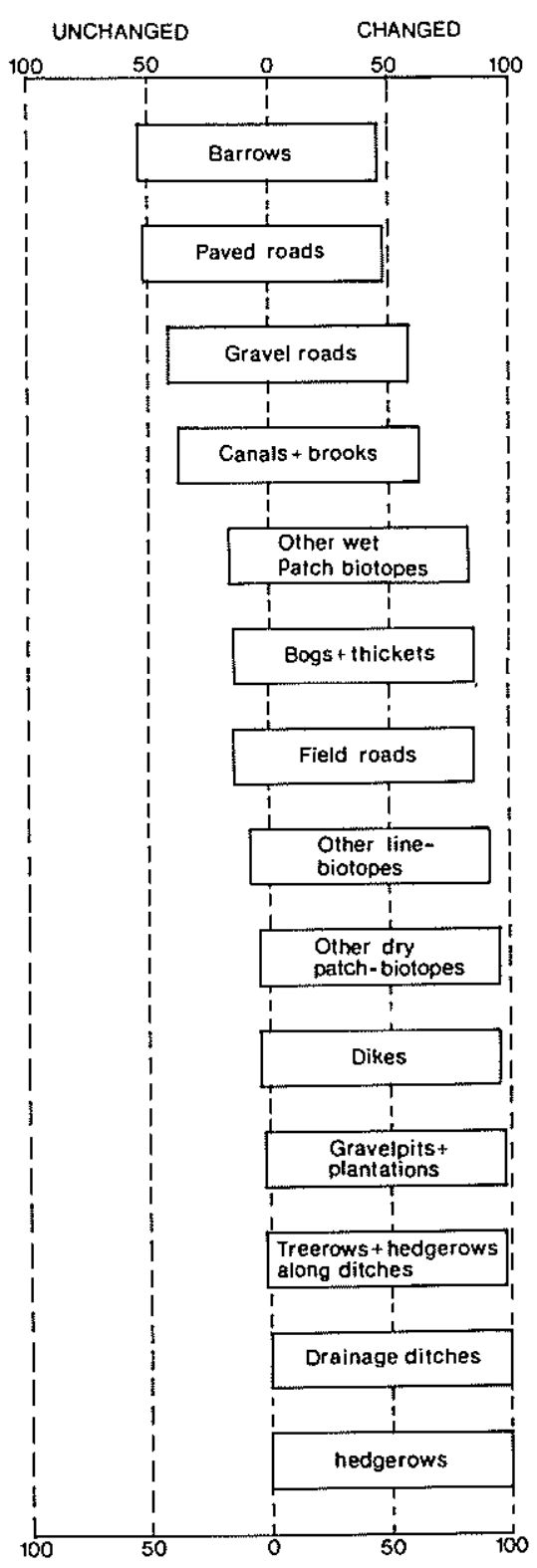

Fig. 4. Stability of the different types of small biotopes in ord of decreasing stability showing what fraction of each bioto has remained the same on all seven registrations since 1885 ( the left of the zero-line).

problems in this analysis. For barrows, it is set that two should have appeared during the peric studied. This, for obvious reasons, cannot 1 the case. The explanation is that some of the ba rows were missing on two consecutive maps an therefore, were recorded as disappeared and lat 
Table 7. The fate of small biotopes during the period 1884 to 1981 for different biotopes grouped by their type in 1981 or where nonexistant that year, its type at first registration.

(For further explanation see the text above)

\begin{tabular}{lccccccc}
\hline & Total number & Unchanged & Changed & Newcomers & Disappeared & Intermediate & LI \\
\hline Roads & 221 & 49 & 14 & 25 & 68 & 65 & .71 \\
Hedgerows & 188 & 2 & 124 & 51 & 2 & 9 & .33 \\
Dikes & 199 & 7 & 13 & 6 & 140 & 33 & .90 \\
Ditches & 324 & 5 & 34 & 41 & 152 & 92 & .87 \\
Canals + brooks & & & & & & & \\
$\quad$ and rivers & 16 & 6 & 8 & 0 & 1 & 1 & .12 \\
Footpaths & 19 & 0 & 0 & 0 & 13 & 6 & .00 \\
Other line-b & 150 & 2 & 4 & 6 & 121 & 17 & .96 \\
Bogs and & & & & & & & \\
$\quad$ thickets* & 88 & 13 & 38 & 11 & 21 & 5 & .42 \\
Ponds** & 282 & 45 & 22 & 8 & 186 & 21 & .76 \\
Barrows & 20 & 11 & 1 & 2 & 3 & 3 & .40 \\
Other dry patch-b.*** & 59 & 2 & 7 & 42 & 2 & 6 & .85 \\
Total line-b & 1117 & 71 & 197 & 129 & 497 & 223 & .76 \\
Total patch-b & 449 & 71 & 68 & 63 & 212 & 35 & .69 \\
\hline
\end{tabular}

* Only self-grown thickets.

** Ponds include here lakes, marl pits and gravel pits.

*** Including planted thickets.

appeared as newcomers.

In spite of these methodological problems, the indicated rank order of increasing lability certainly is valid. Because of the time needed for a natural colonization with plants and the following succession and immigration of the related fauna (often to be counted in hundreds of years), the analysis can be said to have demonstrated nearly chaotic living conditions for anything other than pioneer plant and animal species. Populations of plants and animals in the small biotopes often are hit by catastrophic changes, such as pollution, that cannot be determined from maps and aerial photographs. Clearly, we need to create more stable conditions for these biotopes.

\section{Recent trends}

Changes in small biotopes in 1981 and 1986 are given in Table 8. Generally, the same trends as from 1884 to the late 1970 s are visible in Table 8. It is the smallest and wettest biotopes that are disappearing most rapidly. In the latest period, however, the decline has slowed for all biotopes except ponds. They are still disappearing at a high rate. A new trend is the rapid growth of the group, 'other patchbiotopes', comprized mostly of small abandoned areas.

The development is not the same in all areas. In some, the development in the biotope pattern has stopped, whereas in others (the most intensively cultivated) it has accelerated. In this way, the differentiation between agricultural landscapes is increasing. Further, in 1986 spontaneous marginalization of agricultural land, with nine abandoned fields, was observed. Five years earlier there were none.

\section{Determining factors}

In the fertile and arable Danish landscapes, where agriculture has existed for more than 5000 years, the anthropological influence is overwhelming. More than three-fourths of the patterns of small biotopes can be traced to having been established with a definite agricultural purpose, and the rest 
Table 8. Development of the total content of line-biotopes in $\mathrm{km}$ and patch-biotopes in number registered on aerial photographs and in the field (1981 and 1986) for $5 \times 4 \mathrm{~km}^{2}$.

\begin{tabular}{lcccc}
\hline & 1954 & 1968 & 1981 & 1986 \\
\hline Line-biotopes & 147.4 & 135.0 & 99.6 & 97.1 \\
Wet patch-biotopes & 169 & 147 & 106 & 96 \\
Barrows & 17 & 16 & 14 & 14 \\
Thickets* & 60 & 66 & 69 & 70 \\
Other patch-biotopes & - & - & 17 & 24 \\
& & & & \\
All patch-biotopes & 246 & 229 & 206 & 204 \\
\hline Rate of change & $1954-68$ & $1968-81$ & $1981-86$ \\
in \% per year & \multicolumn{5}{c}{$\begin{array}{l}2 \\
\text { Line-biotopes }\end{array}$} & -0.6 & -2.3 & -0.5 & \\
Wet patch-biotopes & -1.0 & -2.5 & -2.0 \\
Barrows & -0.4 & -1.0 & 0.0 & \\
Thickets* & +0.7 & +0.3 & +0.3 & \\
Other patch-biotopes & - & - & +6.7 & \\
All patch-biotopes & -0.5 & -0.8 & -0.2 & \\
\hline
\end{tabular}

*Including solitary trees.

have been used, permanently or from time to time, for grazing, peat cutting, timber and firewood production. Hence, the history of agriculture is the key to understanding the history of the biotopes.

Agriculture is, however, dependant on the natural potential of the landscape, which influences field size and pattern, type of crops, the installations needed, and often indirectly the general farm size and type of specialization that develops. Therefore, it is almost impossible to separate which anthropogenic and non-anthropogenic factors are influencing development. Even where we have registered several thousand biotopes, any simple objective statistical test for correlation is bound to fail because of the number of possible ways in which the different conditions have influenced the observed pattern.

Instead our approach has been to see whether ecological and agricultural conditions could be correlated with the observed densities.

\section{Ecological conditions}

Geomorphological conditions are known to in- fluence agriculture in Denmark; slopes may preven soil cultivation, soil gives varying conditions fo growing crops and hydrological conditions deter mine the need for drainage and irrigation.

A measurement of the effect of slope was ob tained by counting the number of times the border of each square kilometer were crossed by elevatior contours on the map. This sum has been correlater with the densities of the main types of biotope: within each area. The results showed marked nega tive correlations between relief and the densities o wet linebiotopes, and marked positive correlation with wet patchbiotopes. The dry types did not shov any significant correlations.

Based on existing soil maps, higher densities 0 : dry linebiotopes (especially the shelterbelts) occu on lighter soils. Wet linear biotopes were also unex pectedly common on these soils, which can be ex plained by the many canals and drainage ditches it an area that was situated in a reclaimed fiord. Th organic soil types showed a high density of wet line biotopes, as expected. Wet patch-biotopes were sel dom found on light soils, but are often on cla? (marl pits) and organic soils (bogs). The dry patch biotopes were more often found on lighter soils.

The need for draining may have been the mos important factor in the development of agricultur in Denmark. More than $50 \%$ of the total agricultur al area is drained. Correlation of the areas of organ ic soils with the pattern of wet biotopes indicate tha the percentage of peat soil areas carrying wet patcl biotopes declined from $74 \%$ in 1884 to $37 \%$ is 1981. This decline illustrates the increased agricul tural independance from the conditions set by na ture over this period.

\section{Agricultural conditions}

Nowadays, material input from the biotopes to agricultural production are few and relativel: unimportant. Excavation of raw materials are con centrated in a few, rather big pits. Water for irri gation and watering of cattle is almost entirel: dependant on pumped groundwater. Only in th production of tree products is there some limiter dependence on the biotope. 
The drainage of surplus water is still important for the existence of wet line-biotopes. Most of the biotopes of this type received water from drainpipes. Solid waste coming from households, agricultural production and stones removed from fields was observed in many biotopes. This waste was especially abundant among the wet patch-biotopes. At first, it may cause eutrophication and/or oxygen deficit. In the long run, it leads to their disappearance.

Today, the most important function of the small biotopes in Eastern Denmark seems to be for marking boundaries of fields and estates. In the 13 areas, there were $208 \mathrm{~km}$ of estate boundaries. Of these $88 \%$ carried small biotopes. This percentage varied among the 13 areas (from $52 \%$ to $100 \%$ ) being lowest in the most intensively cultivated and most fertile areas and highest in the newly reclaimed area (area IX). Almost $2 / 3$ of the line-biotopes were found in estate boundaries, this was so for only $35 \%$ of the patch-biotopes. This dependence makes the pattern of small biotopes highly sensitive to future development within the agricultural structure.

Game production is the most important recreational function of the small biotopes. The density of game and hunters in Denmark is extremely high (averaging four hunters per $\mathrm{km}^{2}$ ), and about $95 \%$ of the agricultural area was used for hunting. Game production lead to both preservation and management of existing biotopes and to creation of new ones. This is especially true for patch-biotopes which are planted around existing ponds and thickets.

\section{Discussion}

\section{Classification of the data}

The classification of small landscape elements into different types of small biotopes has not been possible on strictly objective criteria. Rather, it is a compromise between the restrictions of a unique combination of the locality and the time period studied. Only the procedure, but not the types themselves, may be useful in other landscapes.

The information on biotope structures was rather crude. Only locality, type, and size have been discussed above. We attempted to analyze another element, pattern, into classes of different combinations of biotope types. Two types of auto-classification were tried: Cluster Analysis and Principal Component analysis, based on the $134 \mathrm{~km}^{2}$ and the 249 evenly distributed $1 \mathrm{~km}^{2}$ areas. The analyses were carried out on two levels: One where the biotopes were grouped into 18 main types, and one where they were grouped into only four (Brandt 1986).

None of the classifications gave clear results. The reason for these negative results could be of technical origin. It is important to analyze how changes in the size of the squares could influence the results. Detailed tests would presuppose a large-scaled landscape survey of chorological units, and such surveys have not been carried out in Denmark. An inspiration for this type of mapping could be the comprehensive standardization described by Haase et al. (1985).

Information on plant and animal species in the small biotopes is as important for nature conservation as information on the densities of small biotopes. Obtaining biological information is far more time consuming than mere geographical registration of habitats. In such ecological studies, space is only one element among many. Tvevad (1987) gives a comprehensive review (in Danish) of the literature on the biology of small biotopes in Danish landscapes. Additional information is in Arnold (1983), Beebee (1981), Zwoelfer (1984), Mader et al. (1986), Dowdeswell (1987) and ten Houte de Lange (1984).

In the study, species of trees and shrubs were recorded (Agger and Jensen 1982, 1983 and 1984, Biotopgruppen 1986). For each second meter, cross sections were laid along line-biotopes and along lines diagonally crossing the patch-biotopes and the species intersected recorded. This was done in each tenth linebiotope and each fifth patch-biotope.

The analysis demonstrated considerable differences in the species composition among the different biotope types. Syringa vulgaris and Prunus spinosa were typical for hedgerows. Typical for wet patch-biotopes were Salix viminalis and Salix cinerea, for planted patch-biotopes, Picea abies 
and Pinus sp., and for other dry patch-biotopes, Acer pseudoplatanus, Fraxinus excelcior and Fagus sylvatica. A considerable number of species were found in more than one of the types. Sambucus nigra and Crataegus monogyna were the two species found most abundantly in all biotope types.

\section{Perspectives for management}

Small biotopes are characterized by a continuing decrease in their density, especially among the wet biotopes, and a high instability in their pattern, together with frequent occurrances of pollution and disturbance. Protection against removal and pollution is needed. However, such measures of protection must be seen in a broader economic-political context. Declining agricultural prices within the $\mathrm{EEC}$, in combination with growing pressure for non-agricultural use of the open land for forestry, nature conservation and recreation, make it likely that there will be a change in the use of open land within the next years. Officially, it has been estimated that the marginalization of agricultural land will amount to $15 \%$ of the total national territory within the next one or two decades.

In fact, two different directions of change can be seen. Biotope structure may be more stabilized in areas with poorer agricultural conditions, due to less pressure for the land use and more environmental and recreational protection. Areas with better agricultural conditions show an intensification of land use, with a reduction in the number and area of small biotopes (Brandt and Agger 1988). This difference calls for different management strategies.

In areas with spontaneous marginalization, the biotope structure can be preserved mostly through voluntary arrangements. The main problem is accessibility for the public on private land. In areas with good agricultural conditions, more strict regulations are needed. Expropriative conservation can be used, but it is extremely expensive, and is used rarely in areas other than those of special natural or cultural interests. Such areas are seldom concentrated on good agricultural land.

In Denmark, the most important single means of regulation is paragraph 43 in the Nature Conserva tion Act. It states that changes in the beds of ope watercourses, of lakes, bogs, moors, heaths, sal meadows and salt marshes of a certain size requir permission from the nature conservation author ties. Since 1972, the range of biotope types covere by this paragraph has been broadened several time and the minimum size has been lowered (Koeste 1980 and 1984). Today, it forms a useful instrumen for conservation planning of the rural landscape. enables the authorities to practice a diverse ad ministration, restrictive in landscapes where sma biotopes have high priority and more liberal i other areas. Together with other limited means fo establishing and management of private and publi owned small biotopes, paragraph 43 can be used a a tool for the improvement of dispersal of wildlif in the fragmented landscape.

Since roadside verges are one of the only expanc ing elements in the pattern of small biotopes, an estate boundaries still have a high density of sma biotopes, two models are suggested (Agger et a 1987; Brandt and Agger 1988): The road structur model, that indicates where marginalization $c$ fields might satisfy recreational needs, and the $t h$ boundary model, which states that all boundarit around borroughs, parishes and estates shall carr some small biotopes. Both models will form general barrier against further fragmentation of th habitats for wildlife, and at the same time they ca be used as a skeleton for the creation of a new lanc scape as marginalization proceeds.

To some degree, this type of development he received support from an unexpected source. $\mathrm{Tr}$ severe cases of fish death in the Danish seas sinc 1981 caused by oxygen deficit induced by fertilizt runoff from agriculture have made serious counte actions necessary. In the packet of legislative me: sures that are now under discussion in the parli: ment, creation of uncultivated buffer zones alor watercourses probably will come into practice. $\mathrm{B}$ sides limiting the leaching of fertilizers, these zon will serve as dispersal corridors for wildlife.

Finally, it must be stressed, that a close intercol nection with agricultural development and plai ning is a precondition for successful implement: tion of any of these models, especially within th 
more intensively used agricultural landscape. If general price and market regulations continue to dominate agricultural policy, as has been the case within the EEC, such models are deemed to fail.

\section{References}

Agger, P. and Brandt, J. 1984. Registration methods for studying the development of small-scale biotope structures in rural Denmark. In Proceedings of The First International Seminar on Methodology in Landscape Ecological Research and Planning. Vol. II, pp. 61-72. Edited by J. Brandt and P. Agger.

Agger, P. and Brandt, J. 1987. Smaabiotoper og marginaljorder (Small biotopes and marginal soils). Miljoeministeriets projektundersoegelser 1986. Teknikerrapport nr. 35. Skovog Naturstyrelsen.

Agger, P., Andersen, S.S., Brandt, J., Nielsen, T.S., Pedersen, S. and Trevad, A. 1987. Moraenelandets marginaljorder. (The marginal soils of the morainic landscape). Miljoeministeriets projektundersoegelser 1986. Samlerapport nr. VHIla. Skov- og Naturstyrelsen.

Agger, P. and Jensen, S.L. 1982. Hegn og skel i Roskilde amt. (Hedges and field divides the district of Roskilde). Forskningsrapport nr. 32. Institut for Geografi. Samfundsanalyse og Datalogi. Roskilde University Centre.

Agger, P.and Jensen, S.L. 1983. Traeer og buske i hegn og skel. (Trees and bushes in hedges and field divides). pp. 427-432. Ugeskrift for Jordbrug. 23.'

Agger, P. and Jensen, S.L. 1984. A method for quantitative investigation of the vegetation. In Proceedings of The First International Seminar on Methodology in Landscape Ecological Research and Planning. Vol. V, pp. 109-115. Edited by J. Brandt and P. Agger.

Arnold, G.W. 1983. The influence of ditch and hedgerow structure, length of hedgerows, and the area of woodland and garden on bird numbers on farmland. J. App. Ecol. 20: 731-750.

Beebee, T.J.C. 1981. Habitats of the British amphibians (4): Agricultural lowlands and a general discussion of requirements. Biol. Conserv. 21: 111-124.

Biotopgruppen (Agger, Brandt, Byrnak, Jensen og Ursin) 1986. Udviklingen $\mathrm{i}$ agerlandets smaabiotoper iOestdanmark. (The development of small biotopes in the agricultural areas of Eastern Denmark). Forskningsrapport nr. 48. Institut for Geografi, Samfundsanalyse og Datalogi. Roskilde University Centre.

Brandt, J. 1986. Small-biotope structures as a synthetizing feature in agricultural landscapes. In Landscape Synthesis Foundations, Classification and Management. Part I, Geoecological Foundations. pp. 52-62. Edited by H. Richter and G. Schoenfelder. Martin-Luther-Universitaet Halle-Wittenberg. Wissenschaftliche Beitraege 1986/16. Halle(Saale), GDR.

Brandt, J. and Agger, P. (ed.) 1984. The International Association for Landscape Ecology (IALE). Proceedings of the first international seminar on Methodology in Landscape Ecological Research and Planning, Vol, 1-V. Roskilde University Centre, October 1984.

Brandt, J. and Agger, P. 1988. The influence of EEC-agri- cultural policy on the conditions for development of biotope structures in rural landscapes - some Danish experiences. In Connectivity in Landscape Ecology. Proceedings from the 2nd International Seminar of IALE. Muenster, FRG, July 1987. Edited by K.-F. Schreiber (Forthcoming).

Dowdeswell, W.H. 1987. Hedgerows and verges. Allen \& Unwin. Boston.

Ericsson et al. 1987. Poster presented at the 2nd international seminar of IALE. Muenster, FRG, July 1987 . Edited by K.-F. Schreiber (Forthcoming).

Forman, R.T.T. and Godron, M. 1986. Landscape Ecology. John Wiley \& Sons, New York.

Haase, G. et al. 1985. Richtlinie für die Bildung und Kennzeichnung der Kartierungseinheiten der 'Naturraum-typen der DDR im mittleren Masstab'. Institut f. Geographie u. Geoekologie d.A.d.W. der DDR. Wissensch. Mitt. Sonderheft 3. Leipzig.

Ihse, M. 1987. Disappearing biotopes in the rural landscape: Changed conditions for man, mammals and plants. Poster presented at 2nd international seminar of IALE, Muenster, FRG.

Koester, V. 1980. Nordic countries' legislation on the environment with special emphasis on conservation - a survey. IUCN Environmental Policy Law Paper, No. 14.

Koester, V. 1984. Conservation Legislation and General Protection of Biotopes in an International Perspective. Environ. Pol. Law. 12(4): 106-116.

Mader, H.J. et al. 1986. Experiments zum Biotopverbundsystem -- tieroekologische Untersuchungen an einer Anpflanzung. Schriftreihe für Landschaftpflege und Naturschutz. Heft 27.

Moore, N.W. 1977. Arable land. In Conservation and Agriculture. pp. 23-43. Edited by J. Davidson and R. Lloyd. Wiley and Sons, New York.

Naveh, Z. 1984. Towards a transdisciplinary conceptual framework of landscape ecology. In Proceedings of The First International Seminar on Methodology in Landscape Ecological Research and Planning. Vol. I. pp. 35-45. Edited by J. Brandt and P. Agger.

Ruthsatz, B. and Haber, W. 1982. The significance of smallscale landscape elements in rural areas as refuges for endangered plant species. In Perspectives in Landscape Ecology, pp. 117-124. Edited by S.P. Tjallingi and A.A. de Veer. Pudoc, Wageningen.

Schmel, H.J. and Englmaier, A. 1982. Zur Bedeutung naturnaher Kleinstrukturen für die Landwirtschaft im Rahmen der Flurbereinigung. Z.f. Kulturtechn. Flurber. 23: 75-86.

Ten Houte de Lange, S.M. 1984. Effects of landscape structure on animal population dynamics. In Proceedings of The First International Seminar on Methodology in Landscape Ecological Research and Planning. Vol. I. pp. 19-31. Edited by J. Brandt and P. Agger.

Tvevad, A. 1987. Smaabiotopernes betydning for flora og fauna. Marginaljorder og miljoeinteresser. (The importance of small biotopes for flora and fauna. Marginal soils and environmental interests. Miljoeministeriets projektundersoegelser 1986. Teknikerrapport nr. 38.

Zwoelfer et al. 1984. Die tierokologische Bedeutung und Bewertung von Hecken. Berichten der Akademie für Naturschutz und Landschaftpflege. Laufen/Zalzach. 